\title{
Pengembangan Perangkat Pembelajaran Berbasis Pendekatan Matematika Realistik untuk Meningkatkan Kemampuan Pemecahan Masalah dan Kemandirian Belajar
}

\author{
Ainul Marhamah Hasibuan ${ }^{1}$, Sahat Saragih $^{2}$, Zul Amry ${ }^{3}$
}

\begin{abstract}
ABSTRAK
Penelitian ini bertujuan untuk mendeskripsikan: 1) validitas perangkat pembelajaran berbasis PMR yang dikembangkan 2) kepraktisan perangkat pembelajaran berbasis PMR yang dikembangkan; 3) efektivitas perangkat pembelajaran berbasis PMR yang dikembangkan; 4) peningkatan kemampuan pemecahan masalah siswa dengan menggunakan perangkat pembelajaran berbasis PMR yang dikembangkan; 5) peningkatan kemandirian belajar siswa dengan menggunakan perangkat pembelajaran berbasis PMR yang dikembangkan; 6) proses jawaban siswa dalam menyelesaikan soal-soal kemampuan pemecahan masalah. Penelitian ini adalah penelitian pengembangan. Dari hasil uji coba I dan uji coba II diperoleh: 1) perangkat pembelajaran berbasis PMR yang dikembangkan valid dengan rata-rata total validitas $\mathrm{RPP}=4,46$, buku siswa $=4,41$, LAS $=4,31 ; 2$ ) perangkat pembelajaran berbasis PMR yang dikembangkan praktis ditinjau dari a) penilaian ahli/praktis dapat digunakan dengan sedikit revisi; dan b) keterlaksanaan perangkat yaitu pada uji coba I dengan rata-rata sebesar 85\% dan meningkat pada uji coba II sebesar 91,25\%. 3) perangkat pembelajaran berbasis PMR yang dikembangkan efektif, ditinjau dari a) ketuntasan belajar siswa secara klasikal pada uji coba I 62\% meningkat pada uji coba II telah tercapai 92\%.; dan b) respon siswa terhadap komponen-komponen pembelajaran positif; 4) terdapat peningkatan kemampuan pemecahan masalah matematis siswa dengan menggunakan perangkat pembelajaran berbasis PMR yang dikembangkan pada uji coba I memperoleh rata-rata nilai posttest $72 \%$, dan meningkat pada uji coba II dengan rata-rata nilai posttest 92\%; 5) terdapat peningkatan kemandirian belajar siswa dengan menggunakan perangkat pembelajaran berbasis PMR yang dikembangkan pada uji coba I memperoleh nilai rata-rata 65,69 dan meningkat pada uji coba II dengan memperoleh nilai rata-rata 71,37; 6) proses jawaban siswa pada uji coba II lebih baik dari uji coba I.
\end{abstract}

Kata Kunci: pengembangan perangkat pembelajaran, model 4-D, pembelajaran berbasis PMR, pemecahan masalah, kemandirian belajar

\section{PENDAHULUAN}

Pendidikan adalah upaya untuk memajukan tumbuhnya budi pekerti (kekuatan batin, karakter), pikiran (intelek) dan tumbuh peserta didik untuk memajukan kehidupannya selaras dengan dunianya. Dalam pendidikan diberikan tuntunan oleh pendidik kepada pertumbuhan peserta didik untuk menunjukkan kehidupannya (Daulay, 1998). Pendidikan juga merupakan hal yang tidak dapat dipisahkan dari kehidupan manusia. Pentingnya pendidikan, sehingga menjadi tolak ukur kemajuan suatu bangsa. Bangsa yang maju adalah bangsa yang memiliki sumber daya manusia yang berkualitas, baik dari segi spritual, intelegensi maupun skill. Salah satu cara yang dapat dilakukan untuk mencapai tujuan tersebut adalah pembaruan secara berkelanjutan dalam bidang pendidikan khususnya pelajaran matematika.

Matematika memiliki peranan yang sangat penting dalam kehidupan sehari-hari. Cornelius dalam (Mulyono, 2003) mengemukakan bahwa ada lima

\footnotetext{
${ }^{1}$ Corresponding Author: Ainul Marhamah Hasibuan

Program Magister Pendidikan Matematika, Universitas Negeri Medan, Medan, 20221, Indonesia

E-mail: ainulmarhamahhsb@gmail.com

${ }^{2}$ Co-Author: Sahat Saragih \& Zul Amry

Program Studi Pendidikan Matematika,Universitas Negeri Medan, Medan, 20221, Indonesia
}

alasan mengapa matematika perlu dipelajari yaitu:” 1) matematika merupakan sarana berpikir yang jelas dan logis, 2) sarana memecahkan masalah kehidupan sehari-hari, 3) sarana mengenal pola-pola hubungan dan generalisasi pengalaman, 4) sarana untuk mengembangkan kreativitas, dan 5) sarana untuk meningkatkan kesadaran terhadap budaya". Hal ini sejalan dengan tujuan umum pembelajaran matematika yang dirumuskan National Council of Teacher Mathematics (2000) yaitu: (1) belajar untuk berkomunikasi (mathematical communication); (2) belajar untuk bernalar (mathematical reasoning); (3) belajar untuk memecahkan masalah (mathematical problem solving); (4) belajar untuk mengaitkan ide (mathematical connection); (5) pembentukan sikap positif terhadap matematika (positive attitudes toward mathematics) (Somakin, 2010). Uraian di atas menunjukkan bahwa kemampuan matematika siswa merupakan faktor yang sangat penting bagi perkembangan kognitif siswa dan mempengaruhi hasil belajar.

Berdasarkan hasil penelitian Dahlan (2012) kemampuan berpikir tingat tinggi itu terdiri dari: kemampuan berpikir logis, kritis, sistematis, analitis, kreatif, produktif, penalaran, koneksi, komunikasi, dan pemecahan masalah. Sejalan dengan pendapat Saragih \& Napitupulu (2015) bahwa: "The students are expected to use mathematics and mathematical mindset in daily life, and to study many kinds of sciences which 
Vol. 13, No.1, Juni 2020

stress to logical arrangement and student's character building and also ability to apply mathematics".

Salah satu dari kemampuan tingkat tinggi yang diteliti oleh peneliti adalah kemampuan pemecahan masalah matematis. Menurut Rohmah \& Sutiarso (2017) pada penlitiannya bahwa, "problem solving is the interaction between knowledge and application process errors that use cognitive and affective factors in problem solving". Maknanya bahwa pemecahan masalah adalah interaksi antara pengetahuan dan kesalahan yang menggunakan proses penerapan faktor kognitif dan afektif dalam pemecahan masalah.

Surya dan Rahayu (2017), juga mengatakan pada penlitiannya bahwa, pemecahan masalah juga merupakan bagian yang sangat penting dalam pembelajaran matematika. Hal ini disebabkan pemecahan masalah merupakan sarana untuk mengasah penalaran yang cermat, logis, kritis, analitis, dan kreatif. Melalui pemecahan masalah matematis, memungkinkan siswa menjadi lebih analitis dalam mengambil keputusan di dalam hidupnya. Kemampuan pemecahan masalah sangat penting dalam kehidupan sehari-hari, Sebab kita tidak akan pernah lepas dari masalah.

Pentingnya kemampuan pemecahan masalah ini sejalan dengan pendapat In'am (2014) bahwa "Problem solving is a mental process requiring one to think critically and creatively, to look for alternative ideas and specific steps in order to cope with any hindrances or flaws". Maknanya adalah Pemecahan masalah adalah proses mental yang mengharuskan seseorang untuk berpikir kritis dan kreatif, untuk mencari ide alternatif dan langkah-langkah spesifik untuk mengatasi rintangan atau kekurangan apa pun.

Dari pendapat-pendapat di atas, sudah sewajarnya kemampuan pemecahan masalah harus mendapat perhatian khusus, melihat peranannya sangat strategis dalam mengembangkan potensi intelektual siswa. Namun kenyataannya kemampuan pemecahan masalah siswa masih rendah. Terdapat pada penelitian Rohmah \& Sutiarso (2017) bahwa:

"Factors that cause errors when viewed from student learning difficulties and abilities are outlined as follows: 1) Students are not able to Absorb Information Well, 2) The Lack of Experience of Students in Working on the Problem, 3) Students do not Understand the Material Thoroughly, 4) Weak Ability of the Concept of Prerequisites, 5) Negligence or Carelessness of Students".

Maksud dari penelitian tersebut adalah, Faktor yang menyebabkan kesalahan bila dilihat dari kesulitan dan kemampuan belajar siswa diuraikan sebagai berikut:1) Siswa tidak mampu menyerap informasi dengan baik, 2) Kurangnya Pengalaman Siswa dalam Mengerjakan yang sulit, 3) Siswa tidak mengerti materi secara seksama, 4) Kemampuan Lemah dari Konsep Prasyarat, 5) Kelalaian atau Kecerobohan Siswa (pada proses pengerjaan).

Sejalan dengan penelitian awal yang dilakukan Saragih dan Habeahan (2014) menyatakan bahwa dalam pemecahan masalah, sering ditemukan bahwa siswa hanya fokus dengan jawaban akhir tanpa memahami bagaimana proses jawabannya benar atau tidak. Hasil yang sering muncul bahwa jawaban siswa salah.

Selain pentingnya kemampuan pemecahan masalah matematis, hal lain yang dianggap penting adalah sikap siswa dalam mempelajari matematika yang salah satunya adalah kemandirian belajar siswa. Kemandirian belajar berkaitan dengan belajar mandiri namun bukanlah belajar sendiri atau memisahkan siswa dari siswa lainnya. Seperti halnya yang diungkapkan oleh Mu'tadin (2002) yaitu belajar mandiri bukan merupakan usaha untuk mengasingkan siswa dari teman belajar. Siswa boleh bertanya, berdiskusi ataupun meminta penjelasan dari orang lain. Kemandirian belajar akan terbentuk dari proses belajar mandiri.

Sejalan pada penelitian Pratama, dkk (2017)" Independence in learning is a necessity and demand in education today" . Maksudnya adalah bahwa kemandirian dalam belajar merupakan kebutuhan dan kebutuhan dalam pendidikan saat ini. Fahradina, dkk (2014) Mengungkap karakteristik utama self-study adalah pengembangan kemampuan siswa untuk melakukan proses pembelajaran yang tidak bergantung pada faktor guru, teman, kelas dan lain-lain.

Salah satu faktor penting yang dapat meningkatkan kemampuan matematika adalah untuk melakukan pembelajaran yang berkualitas dengan membuat perangkat pembelajaran yang tepat. Penggunaan perangkat pembelajaran memberikan manfaat yang baik dalam pembelajaran. Tujuan pengembangan perangkat pembelajaran adalah untuk meningkatkan dan menghasilkan produk baru. Selain itu, bertujuan untuk menghasilkan perangkat pembelajaran yang mampu memecahkan masalah pembelajaran di kelas, karena pada intinya tidak ada satu sumber pembelajaran yang dapat memenuhi semua jenis kebutuhan proses pembelajaran. Dengan kata lain pemilihan alat belajar, perlu dikaitkan dengan tujuan yang ingin dicapai dalam proses pembelajaran, terutama dalam meningkatkan keterampilan matematika siswa, terutama kemampuan memahami konsep matematika dan belajar mandiri siswa.

Oleh karena itu, penting bagi guru untuk dapat mengembangkan perangkat pembelajaran untuk mendukung efektivitas dan efisiensi pembelajaran, sehingga apa tujuan pembelajaran dapat tercapai dengan baik. Perangkat pembelajaran dikatakan memenuhi syarat jika memenuhi kriteria yang valid, praktis, dan efektif.

Menyikapi permasalahan yang ada dalam pembelajaran matematika seperti yang telah diuraikan di atas, terutama berkaitan dengan kemampuan pemecahan masalah matematis, kemandirian belajar siswa, pendekatan dalam pembelajaran dan perangkat pembelajaran. Maka perlu bagi guru atau peneliti memilih model, pendekatan, strategi maupun metode pembelajaran. Sejalan pada penelitian Laurens, dkk (2017) bahwa "It is necessary for the teachers to develop more appropriate learning media, strategies, or model which are more suitable with learning materials or with the contexts that their students are 
dealing with". Maksudnya dalah, bahwa Penting bagi para guru untuk mengembangkan media pembelajaran, strategi, atau model pembelajaran yang lebih tepat, yang lebih sesuai dengan materi pembelajaran atau dengan konteks yang dihadapi siswa.

Selanjutnya, Zakaria dan Muzakkir (2017) menyatakan dalam penelitiannya bahwa "Realistic Mathematics Education Approach is an appropriate methods to improve the quality of teaching and learning process". Maknanya bahwa pendekatan RME merupakan metode yang tepat untuk meningkatkan kualitas proses belajar mengajar.

Berdasarkan deskripsi di atas terkait permasalahanpermasalahan yang menyebabkan kemampuan pemecahan masalah matematis dan kemandirian belajar siswa rendah. Maka peneliti akan melakukan penelitian untuk mencari solusi dari permasalahan yang ada dengan mengembangkan perangkat pembelajaran. Hal inilah yang mendorong peneliti untuk melakukan penelitian dengan judul "Pengembangan Perangkat Pembelajaran Berbasis Pendekatan Matematika Realistik (PMR) Untuk Meningkatkan Kemampuan Pemecahan Masalah dan Kemandirian Belajar Siswa SMP Negeri 5 Padangsidimpuan.

\section{KAJIAN TEORITIS}

\section{Kemampuan Pemecahan Masalah Matematis}

Salah satu kemampuan yang diharapkan siswa dalam belajar matematika adalah kemampuan pemecahan masalah atau sering disebut problem solving. Pemecahan masalah melibatkan konteks yang bervariasi yang berasal dari penghubungan masalahmasalah dalam kehidupan sehari-hari untuk situasi matematika yang ditimbulkan (NCTM, 2000). Siswa dapat memecahkan beberapa masalah yang dimunculkan bagi mereka oleh orang lain. Akan tetapi lebih mudah bagi mereka untuk memformulasikan masalah mereka sendiri berdasarkan pengalaman pribadi dan ketertarikan (Atun, 2006). Dalam pemecahan masalah siswa didorong dan diberi kesempatan seluas-luasnya untuk berinisiatif dan berpikir sistematis dalam menghadapi suatu masalah dengan menerapkan pengetahuan yang didapat sebelumnya. indikator pemecahan masalah di atas, Charles, Lester, dan O'Daffer dalam (Szetela \& Nicol, 1982) menyusun indikator dari setiap aspek atau tahap pemecahan masalah: (1) Memahami Masalah (Understanding Problem), (2) Merencanakan Pemecahan Masalah (Solving the Problem), dan (3) Menyelesaikan Masalah (Answer the Problem).

\section{Kemandirian Belajar Siswa}

Chamot dalam (Ellinawati, 2010) menyatakan bahwa, Self Regulated Learning atau pembelajaran mandiri adalah sebuah situasi belajar dimana pembelajar memiliki kontrol terhadap proses pembelajaran tersebut melalui pengetahuan dan penerapan strategi yang sesuai, pemahaman terhadap tugas-tugasnya, penguatan dalam pengambilan keputusan dan motivasi belajar. Sugilar dalam (Tahar, dkk: 2006) merangkum pendapat Guglielmino, West \& Bentley menyatakan bahwa karakteristik individu yang memiliki kesiapan belajar mandiri dicirikan oleh: 1) kecintaan terhadap belajar; 2) kepercayaan diri sebagai siswa; 3) keterbukaan terhadap tantangan belajar; 4) sifat ingin tahu; 5) pemahaman diri dalam hal belajar; dan 6) menerima tanggung jawab untuk kegiatan belajarnya.

Kemandirian belajar memiliki manfaat yang banyak terhadap kemampuan kognitif, afektif, dan psikomotorik siswa yaitu: 1) memupuk tanggung jawab; 2) meningkatkan keterampilan; 3) memecahkan masalah; 4) mengambil keputusan; 5) berpikir kreatif; 6) berpikir kritis; 7) percaya diri yang kuat; dan 8) menjadi guru bagi dirinya sendiri. Kemandirian belajar yang dimiliki siswa dapat diukur melalui indikator.

Menurut Zimmerman (2008) ada delapan indikator kemandiriran belajar siswa, yaitu: (1) evaluasi terhadap kemajuan tugas (self evaluating); (2) mengatur materi pelajaran (organizing and transforming); (3) membuat rencana dan tujuan belajar (goal setting and planning); (4) mencari informasi (seeking information); (5) mengatur lingkungan belajar (enviromental structuring); (6) mengulang dan mengingat (rehearsing and memory); (7) meminta bantuan teman, guru, orang dewasa (seeking per, teacher, adult assistence); (8) mengulang tugas/ tes sebelumnya (review test/work).

\section{Pendekatan Pembelajaran Matematika \\ Realistik}

Zulkardi dan Ilma (2010) mendefinisikan pembelajaran matematika realistik adalah teori pembelajaran yang bertitik tolak dari hal-hal 'real' bagi siswa, menekankan ketrampilan 'process of doing mathematics', berdiskusi dan berkolaborasi, berargumentasi dengan teman sekelas sehingga mereka dapat menemukan sendiri ('student inventing' sebagai kebalikan dari 'teacher telling') dan pada akhirnya menggunakan matematika itu untuk menyelesaikan masalah baik individual maupun kelompok.

Selain itu, menurut Grevemeijer dalam (fauzan \& yerizon 2013) bahwa ada tiga prinsip dalam PMR, yaitu: 1) penemuan terbimbing melalui matematika secara progressif; 2) penomena pembelajaran; dan 3) pengembangan model mandiri. Serta memiliki lima karakteristik yang dikemukakan oleh Grevemeijer dalam Zulkardi dan Ilma (2010) yaitu: 1) menggunakan masalah kontekstual; (2) menggunakan model; (3) menggunakan kontribusi siswa; (4) terjadinya interaksi dalam proses pembelajaran; (5) menggunakan berbagai teori belajar yang relevan, saling terkait, dan integrasi dengan topik pembelajaran lainnya.

Adapun langkah-langkah pembelajaran menggunakan pendekatan Pembelajaran Matematika Realistik menurut Fauzi (2002) adalah: 1) memahami masalah kontekstual; 2) menjelaskan masalah kontekstual, 3) menyelesaikan masalah kontekstual; 4) membandingkan atau mendiskusikan jawaban; dan 5) menyimpulkan 


\section{METODE PENELITIAN}

Penelitian ini dikategorikan ke dalam jenis Penelitian Pengembangan (Development Research) dengan menggunakan model pengembangan perangkat pembelajaran Thiagarajan, Semmel dan Semmel (1974) yaitu model 4-D (define, design, develop, and disseminate).

\section{Subjek dan Objek Penelitian}

Subjek dalam penelitian ini adalah siswa VII-3 dan VII-4 SMP Negeri 5 Padangsidimpuan tahun ajaran 2017/2018, dan objek dalam penelitian ini adalah perangkat pembelajaran melalui PMR, dalam penelitian ini yang akan dikembangkan adalah perangkat pembelajaran matematika materi bangun datar segi empat berupa Rencana Pelaksanaan Pembelajaran (RPP), Buku Siswa (BS), Lembar Kerja Siswa (LAS), tes hasil kemampuan pemecahan masalah (TKPM) dan Angket kemandirian belajar siswa (AKB).

Tabel 1. Instrumen dan teknik analisis data

\begin{tabular}{|c|c|c|c|}
\hline $\begin{array}{c}\text { Aspek } \\
\text { yang } \\
\text { dinilai }\end{array}$ & Instrumen & $\begin{array}{l}\text { Data yang } \\
\text { diamati }\end{array}$ & Responden \\
\hline $\begin{array}{l}\text { Validasi } \\
\text { perangkat } \\
\text { pembelajar } \\
\text { an berbasis } \\
\text { PMR }\end{array}$ & $\begin{array}{l}\text { Lembar } \\
\text { validasi }\end{array}$ & $\begin{array}{l}\text { RPP, buku } \\
\text { siswa, LAS, } \\
\text { Kemampuan } \\
\text { Pemecahan } \\
\text { masalah, dan } \\
\text { kemandirian } \\
\text { belajar }\end{array}$ & $\begin{array}{c}\text { Expert/Spec } \\
\text { ialist }\end{array}$ \\
\hline $\begin{array}{l}\text { Praktis } \\
\text { perangkat } \\
\text { pembelajar } \\
\text { an berbasis } \\
\text { PMR }\end{array}$ & $\begin{array}{l}\text { Lembar } \\
\text { Observasi }\end{array}$ & $\begin{array}{c}\text { Keterlaksanaa } \\
n \\
\text { pembelajaran }\end{array}$ & Observer \\
\hline \multirow{2}{*}{$\begin{array}{l}\text { Efektifitas } \\
\text { perangkat } \\
\text { pembelajar } \\
\text { an berbasis } \\
\text { PMR }\end{array}$} & Tes & $\begin{array}{c}\text { Tes } \\
\text { Kemampuan } \\
\text { pemecahan } \\
\text { masalah }\end{array}$ & Siswa \\
\hline & Pertanyaan & Respon Siswa & Siswa \\
\hline
\end{tabular}

Pengembangan perangkat pembelajaran dikatakan berkualitas jika memenuhi tiga aspek yaiitu valid, praktis dan efektif. Perangkat pembelajaran memiliki derajat validitas yang baik apabila minimal tingkat validitas yang dicapai berada pada kategori valid. Jika tingkat validitas berada dibawah kategori valid maka dilakukan revisi kembali berdasarkan masukan para validator. Revisi dilakukan seterusnya sampai diperoleh perangkat pembelajaran yang valid. Kegiatan yang dilakukan untuk menganalisis data ini adalah:

a) Melakukan rekapitulasi data penilaian kevalidan perangkat pembelajaran ke dalam tabel yang meliputi: aspek $\left(\mathrm{A}_{\mathrm{i}}\right)$, indikator $\left(\mathrm{I}_{\mathrm{i}}\right)$, dan nilai $\mathrm{V}_{\mathrm{ji}}$ untuk tiap-tiap ahli.

b) Menentukan rata-rata nilai dari ahli untuk setiap indikator dengan rumus:

$$
I_{i}=\frac{\sum_{j=1}^{n} V_{j i}}{n}
$$

(Ja'far,dkk:2014)

Keterangan:

$\mathrm{V}_{j i}$ : Data nilai dari penilai ke- $j$ terhadap indikator ke- $i$,

$n \quad$ : Banyaknya penilai (ahli dan praktisi)

c) Menentukan rerata nilai untuk setiap aspek dengan rumus:

$$
A_{i}=\frac{\sum_{j=1}^{m} I_{i j}}{m}
$$

(Ja'far,dkk:2014)

Keterangan:

$A_{i}$ : Rerata nilai untuk aspek ke- $i$,

$\mathrm{I}_{i j}$ : Rerata untuk aspek ke-iindikator ke-j,

$m$ : Banyaknya indikator dalam aspek ke- $i$

d) Menentukan nilai $\mathrm{Va}$ atau nilai rerata total dari rerata nilai untuk semua aspek dengan rumus:

$$
V a=\frac{\sum_{i=1}^{n} A_{i}}{n}
$$

Keterangan :

$V a$ : Nilai rerata total untuk semua aspek

$A_{i}$ : Rerata nilai untuk aspek ke- $i$,

$n \quad$ : Banyaknya aspek

Hasil yang diperoleh kemudian ditulis pada kolom dalam tabel yang sesuai. Selanjutnya nilai $V a$ atau nilai rerata total ini dirujuk pada interval penentuan tingkat kevalidan perangkat pembelajaran yang berbasis pendekatan PMR, dapat dilihat pada Tabel 2 berikut:

Tabel 2. Kriteria Tingkat Kevalidan

\begin{tabular}{lcc}
\hline No & $\boldsymbol{V} \boldsymbol{a}$ atau nilai rerata total & $\begin{array}{c}\text { Kriteria } \\
\text { Kevalidan }\end{array}$ \\
\hline 1 & $1 \leq V a<2$ & Tidak valid \\
\hline 2 & $2 \leq V a<3$ & Kurang valid \\
\hline 3 & $3 \leq V a<4$ & Cukup valid \\
\hline 4 & $4 \leq V a<5$ & Valid \\
\hline 5 & $V a=5$ & Sangat valid \\
\hline
\end{tabular}

Perangkat pembelajaran dikatakan praktis jika validator menyatakan bahwa Perangkat pembelajaran yang dikembangkan dapat digunakan di lapangan dengan sedikit revisi atau tanpa revisi. Hasil lembar observasi pada saat proses pembelajaran dengan Perangkat pembelajaran dapat menunjukkan peningkatan yang positif terhadap keterlaksanaan pembelajaran. Data yang diperoleh dari hasil observasi pembelajaran dihitung persentase keterlaksanaannya untuk setiap pertemuan, dengan cara sebagai berikut

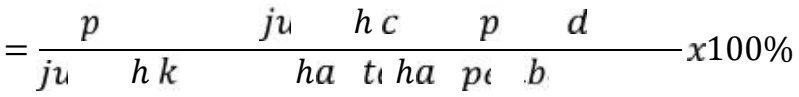


Vol. 13, No.1, Juni 2020

Selanjutnya dihitung rata-rata persentase pertemuan secara keseluruhan. Adapun kriteria penilaian keterlaksanaan kegiatan pembelajaran seperti disajikan pada Tabel 3 berikut:

Tabel 3 Kriteria Penilaian Keterlaksanaan Kegiatan Pembelajaran

\begin{tabular}{|c|c|c|}
\hline Nilai & Interval Skor & Kriteria \\
\hline A & $k>90$ & Sangat Baik \\
\hline B & $80<k \leq 90$ & Baik \\
\hline C & $70<k \leq 80$ & Cukup \\
\hline D & $60<k \leq 70$ & Kurang \\
\hline E & $k \leq 60$ & Sangat Kurang \\
\hline
\end{tabular}

Produk yang dikembangkan dikatakan terlaksana jika persentase rata-rata keterlaksanaan kegiatan pembelajaran menenuhi kriteria minimal "Baik".

Perangkat pembelajaran dikategorikan efektif jika hasil pembelajaran menggunakan Perangkat pembelajaran menunjukkan: 1) Ketuntasan belajar siswa secara klasikal terpenuhi, 2) respon siswa terhadap pembelajaran positif. Setiap siswa dikatakan tuntas belajarnya (ketentuan individu) jika proporsi jawaban benar $75 \%$ dan suatu kelas dikatakan tuntas belajarnya (ketentuan klasikal) jika dalam kelas tersebut terdapat $85 \%$ siswa tuntas belajarnya (Trianto, 2011).

1) Untuk menentukan ketuntasan belajar siswa (individu) digunakan persamaan

$$
K B=\frac{T}{T_{t}} \times 100
$$

Keterangan :

$$
\begin{array}{ll}
K B & : \text { Ketuntasan Belajar } \\
T & \text { : Jumlah skor yang diperoleh siswa } \\
T_{t} & \text { : Jumlah skor total }
\end{array}
$$

Kriterianya :

$$
0 \% \leq \mathrm{PKB}<75 \% \quad=\text { siswa belum tuntas belajar }
$$$$
75 \% \leq \mathrm{PKB}<100 \% \quad=\text { siswa telah tuntas belajar }
$$

$\mathrm{PKB}=$ Persentase Ketuntasan Belajar

Setiap siswa dikatakan tuntas belajar (ketuntasan

individu) jika nilai akhir tes siswa $75 \%$

2) Untuk menghitung ketuntasan belajar secara klasikal digunakan rumus:

$$
P=\frac{\sum x_{\bar{i}}}{n_{\bar{l}}} \times 100 \%
$$

Keterangan:

$$
\begin{array}{ll}
\text { PKK } & \text { : Persentase ketuntasan klasikal } \\
\sum x_{i} & \text { : Jumlah siswa yang tuntas belajar } \\
n_{i} & \text { : Jumlah seluruh siswa }
\end{array}
$$

Kriteria ketuntasan belajar siswa secara klasikal terpenuhi jika dalam kelas tersebut terdapat $\geq 85 \%$ siswa telah tuntas belajar

3) menentukan presentase respon siswa yang memberikan tanggapan sesuai dengan kriteria dengan rumus berikut:
Persentase respon siswa $=\frac{A}{B} \times 100 \%$

(Herman, 2012)

Keterangan :

A = proporsi siswa yang memberikan respon positif

$\mathrm{B}=$ jumlah siswa yang menjadi responden

Interpretasi rata-rata skor angket pada Tabel 4 dengan menggunakan skala Likert yang dimodifikasi dari (Riduan, 2010) :

Tabel 4. Kategori Respon Siswa dalam Kegiatan Pembelajaran

\begin{tabular}{ccc}
\hline No & $\begin{array}{c}\text { Persentase respon } \\
\text { siswa (\%) }\end{array}$ & Kategori \\
\hline 1. & $81-100$ & Sangat Positif \\
\hline 2. & $61-80$ & Positif \\
\hline 3. & $41-60$ & Cukup Positif \\
\hline 4. & $21-40$ & Tidak Positif \\
\hline 5. & $0-20$ & Sangat Tidak Positif \\
\hline
\end{tabular}

Minimal $80 \%$ dari banyak subjek yang diteliti memberikan respon positif terhadap perangkat yang telah dikembangkan.

Untuk melihat peningkatan kemampuan pemecahan masalah siswa setelah mendapatkan pembelajaran digunakan rumus $N$-gain (Hakee, 1999) sebagai berikut:

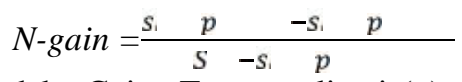

Kriteria Indeks Gains Ternormalisasi $(g)$ atau $N$-gain adalah:

$$
N \text {-gain }>0,7 \quad \text { : tinggi }
$$

$0,3<N$-gain $\leq 0,7 \quad$ : sedang

$N$-gain $\leq 0,3 \quad$ : rendah

Untuk melihat hasil angket kemandirian belajar setiap siswa menggunakan rumus berikut:

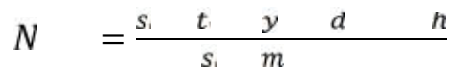

Tabel 5. Kriteria Hasil Kemandirian Belajar Siswa

\begin{tabular}{cc}
\hline Skor Siswa & Kategori \\
\hline $76 \%-100 \%$ & Baik \\
\hline $56 \%-75 \%$ & Cukup \\
\hline $40 \%-55 \%$ & Kurang \\
\hline$<40 \%$ & Tidak baik \\
\hline
\end{tabular}

\section{HASIL PENELITIAN}

Hasil kegiatan uji coba perangkat menghasilkan data kevalidan, kepraktisan, dan keefektifan. Data kevalidan diperoleh dari dua dosen pendidikan matematika yang menilai perangkat pembelajaran yang dikembangkan. Hasil validasi perangkat pembelajaran seperti terlihat pada Tabel 6 . 
Vol. 13, No.1, Juni 2020

\begin{tabular}{llcc} 
Tabel 6. Rangkuman Hasil Validasi Perangkat \\
\multicolumn{4}{c}{ Pembelajaran oleh Ahli } \\
\hline \multirow{2}{*}{ No } & $\begin{array}{c}\text { Objek yang } \\
\text { dinilai }\end{array}$ & $\begin{array}{c}\text { Nilai rata-rata } \\
\text { total validitas }\end{array}$ & $\begin{array}{c}\text { Tingkat } \\
\text { Validasi }\end{array}$ \\
\hline 1 & BS & 4,41 & Valid \\
2 & RPP & 4,46 & Valid \\
3 & LAS & 4,31 & Valid \\
4 & TKPM & - & Valid \\
5 & AKB & - & Valid \\
\hline
\end{tabular}

\section{Uji Coba I}

Kepraktisan perangkat diperoleh dari hasil penilaian observasi keterlaksanaan pembelajaran, penilaian oleh guru. Kepraktisan dari hasil observasi keterlaksanaan pembelajaran dipenuhi jika keterlaksanaan pembelajaran mencapai kategori minimal baik. Hasil observasi keterlaksanaan pembelajaran disajikan pada Tabel 7.

Tabel 7. Hasil Observasi Pelaksanaan Pembelajaran Matematika Berbasis PMR Uji Coba I

\begin{tabular}{cc}
\hline $\begin{array}{c}\text { Pertemuan } \\
\text { ke- }\end{array}$ & $\begin{array}{c}\text { Persentase Keterlaksanaan } \\
\text { Pembelajaran }\end{array}$ \\
\hline 1 & $80 \%$ \\
\hline 2 & $85 \%$ \\
\hline 3 & $85 \%$ \\
\hline 4 & $90 \%$ \\
\hline Rata-rata & $85 \%$ \\
\hline
\end{tabular}

Berdasarkan data hasil observasi keterlaksanaan pembelajaran, diketahui bahwa rata-rata persentase keterlaksanaan pembelajaran sebesar $85 \%$. Ini berarti bahwa rata-rata presentase keterlaksanaan terletak pada interval $80<\mathrm{k} \leq 90$. Dengan demikian, keterlaksanaan pembelajaran menggunakan perangkat pembelajaran matematika realistik yang dihasilkan memenuhi kategori Baik. Ini berarti perangkat pembelajaran matematika realistik yang dihasilkan memenuhi kategori praktis untuk digunakan ditinjau dari analisis observasi keterlaksanaan pembelajaran.

Analisis keefektifan perangkat pembelajaran ditinjau dari: (1) Ketuntasan belajar siswa secara klasikal yaitu $85 \%$ Siswa yang mengikuti tes kemampuan pemecahan masalah telah memperoleh nilai tes kemampuan pemecahan masalah $\geq 75$; dan (2) minimal $80 \%$ siswa merespon positif terhadap perangkat pembelajaran yang dikembangkan. Kriteria keefektifan perangkat pembelajaran ditinjau dari tes kemampuan pemecahan masalah didasarkan pada ketuntasan hasil postest. Kegiatan pretest tetap dilakukan sebatas untuk mengetahui kondisi kemampuan awal siswa sebelum mempelajari materi. Rekapitulasi ketuntasan tes dapat dilihat pada Tabel 8 .
Tabel 8. Tingkat Ketuntasan Klasikal Kemampuan Pemecahan Masalah Matematis pada Uji Coba I

\begin{tabular}{|c|c|c|c|c|}
\hline \multirow{2}{*}{ Kategori } & Pretest & \multirow{2}{*}{$\begin{array}{c}\text { Persen } \\
\text { tase }\end{array}$} & \multirow{2}{*}{$\begin{array}{c}\text { Postest } \\
\begin{array}{c}\text { Jumlah } \\
\text { siswa }\end{array}\end{array}$} & \multirow{2}{*}{$\begin{array}{c}\text { Persen } \\
\text { tase }\end{array}$} \\
\hline & $\begin{array}{c}\text { Jumlah } \\
\text { siswa }\end{array}$ & & & \\
\hline Tuntas & 13 & $50 \%$ & 16 & $62 \%$ \\
\hline $\begin{array}{c}\text { Tidak } \\
\text { Tuntas }\end{array}$ & 13 & $50 \%$ & 10 & $38 \%$ \\
\hline Jumlah & 26 & $100 \%$ & 26 & $100 \%$ \\
\hline
\end{tabular}

Berdasarkan data pada Tabel 8 terlihat bahwa ketuntasan belajar siswa secara klasikal dari hasil kemampuan pemecahan masalah matematis siswa pada uji coba I pretest sebesar 50\% dan postest sebesar $62 \%$. Sesuai dengan kriteria ketuntasan hasil belajar siswa secara klasikal, yaitu minimal $85 \%$ siswa yang mengikuti tes kemampuan pemecahan masalah matematis mampu mencapai skor $\geq 75$. Dengan demikian, hasil posttest kemampuan pemecahan masalah matematis belum memenuhi ketuntasan secara klasikal. Jadi dapat disimpulkan bahwa pada uji coba I penerapan perangkat pembelajaran berbasis matematika realistik yang dikembangkan belum memenuhi kriteria pencapaian ketuntasan secara klasikal, maka akan dilakukan uji coba II.

Untuk keefektifan ditinjau dari respon siswa terhadap perangkat pembelajaran yang dikembangkan, dikatakan efektif jika minimal $80 \%$ siswa memberi respon positif. Persentase rata-rata total respon positif siswa pada uji coba I sebesar $89 \%$. Jika hasil analisis ini dirujuk pada kriteria yang ditetapkan, maka dapat disimpulkan bahwa respon siswa terhadap komponen dan kegiatan pembelajaran adalah sangat positif. Sebab, lebih dari $80 \%$ siswa yang memberikan respon positif terhadap komponen perangkat pembelajaran yang dikembangkan.

\section{Uji Coba II}

Kepraktisan perangkat diperoleh dari hasil penilaian observasi keterlaksanaan pembelajaran, penilaian oleh guru. Kepraktisan dari hasil observasi keterlaksanaan pembelajaran dipenuhi jika keterlaksanaan pembelajaran mencapai kategori minimal baik. Hasil observasi keterlaksanaan pembelajaran disajikan pada Tabel 9

Tabel 9. Hasil Observasi Pelaksanaan Pembelajaran Matematika Berbasis PMR Uji Coba II

\begin{tabular}{cc}
\hline $\begin{array}{l}\text { Pertemuan } \\
\text { ke- }\end{array}$ & $\begin{array}{c}\text { Persentase Keterlaksanaan } \\
\text { Pembelajaran }\end{array}$ \\
\hline 1 & $85 \%$ \\
\hline 2 & $90 \%$ \\
\hline 3 & $95 \%$ \\
\hline 4 & $95 \%$ \\
\hline Rata-rata & $91,25 \%$ \\
\hline
\end{tabular}

Berdasarkan data hasil observasi keterlaksanaan pembelajaran, diketahui bahwa rata-rata persentase keterlaksanaan pembelajaran sebesar $91,25 \%$. Ini 
Vol. 13, No.1, Juni 2020

berarti bahwa rata-rata presentase keterlaksanaan terletak pada interval $k>90$. Dengan demikian, keterlaksanaan pembelajaran menggunakan perangkat pembelajaran matematika realistik yang dihasilkan memenuhi kategori Sangat Baik. Ini berarti perangkat pembelajaran matematika realistik yang dihasilkan memenuhi kategori praktis untuk digunakan ditinjau dari analisis observasi keterlaksanaan pembelajaran.

Selanjutnya, analisis keefektifan perangkat pembelajaran ditinjau dari: (1) Ketuntasan belajar siswa secara klasikal yaitu $85 \%$ Siswa yang mengikuti tes kemampuan pemecahan masalah telah memperoleh nilai tes kemampuan pemecahan masalah $\geq 75$; dan (2) minimal $80 \%$ siswa merespon positif terhadap perangkat pembelajaran yang dikembangkan. Kriteria keefektifan perangkat pembelajaran ditinjau dari tes kemampuan pemecahan masalah didasarkan pada ketuntasan hasil postest. Kegiatan pretest tetap dilakukan sebatas untuk mengetahui kondisi kemampuan awal siswa sebelum mempelajari materi. Rekapitulasi ketuntasan tes dapat dilihat pada Tabel 10.

Tabel 10. Tingkat Ketuntasan Klasikal Kemampuan Pemecahan Masalah Matematis pada Uji Coba II

\begin{tabular}{|c|c|c|c|c|}
\hline \multirow[b]{2}{*}{ Kategori } & Pretest & \multirow{2}{*}{$\begin{array}{c}\text { Persen } \\
\text { tase }\end{array}$} & \multirow{2}{*}{$\begin{array}{c}\text { Postest } \\
\text { Jumlah } \\
\text { siswa }\end{array}$} & \multirow{2}{*}{$\begin{array}{l}\text { Perse } \\
\text { ntase }\end{array}$} \\
\hline & $\begin{array}{c}\text { Jumlah } \\
\text { siswa }\end{array}$ & & & \\
\hline Tuntas & 20 & $77 \%$ & 24 & $92 \%$ \\
\hline $\begin{array}{c}\text { Tidak } \\
\text { Tuntas }\end{array}$ & 6 & $23 \%$ & 2 & $8 \%$ \\
\hline Jumlah & 26 & $100 \%$ & 26 & $100 \%$ \\
\hline
\end{tabular}

Berdasarkan data pada Tabel 9 terlihat bahwa ketuntasan belajar siswa secara klasikal dari hasil kemampuan pemecahan masalah matematis siswa pada uji coba II pretest sebesar $77 \%$ dan postest sebesar 92\%. Sesuai dengan kriteria ketuntasan hasil belajar siswa secara klasikal, yaitu minimal $85 \%$ siswa yang mengikuti tes kemampuan pemecahan masalah matematis mampu mencapai skor $\geq 75$. Dengan demikian, hasil posttest kemampuan pemecahan masalah matematis telah memenuhi ketuntasan secara klasikal. Jadi dapat disimpulkan bahwa pada uji coba I penerapan perangkat pembelajaran berbasis matematika realistik yang dikembangkan belum memenuhi kriteria pencapaian ketuntasan secara klasikal.

Untuk keefektifan ditinjau dari respon siswa terhadap perangkat pembelajaran yang dikembangkan, dikatakan efektif jika minimal $80 \%$ siswa memberi respon positif. Persentase rata-rata total respon positif siswa pada uji coba II sebesar 90\%. Jika hasil analisis ini dirujuk pada kriteria yang ditetapkan, maka dapat disimpulkan bahwa respon siswa terhadap komponen dan kegiatan pembelajaran adalah sangat positif. Sebab, lebih dari $80 \%$ siswa yang memberikan respon positif terhadap komponen perangkat pembelajaran yang dikembangkan.

Deskripsi peningkatan kemampuan pemecahan masalah menggunakan pengembangan perangkat pemebalajaran berbasis PMR pada uji coba I dan II dapat dilihat pada Tabel 11 berikut:

Tabel 11. Deskripsi Hasil Kemampuan Pemecahan Masalah Matematis

\begin{tabular}{cccccc}
\hline \multirow{2}{*}{ Keterangan } & \multicolumn{2}{c}{ Uji coba I } & \multicolumn{2}{c}{ Uji coba II } \\
\cline { 2 - 5 } & Pretest & Postest & Pretest & Postest \\
\hline \hline $\begin{array}{c}\text { Nilai } \\
\text { Tertinggi }\end{array}$ & 85 & 97,5 & 87,5 & 97,5 \\
\hline $\begin{array}{c}\text { Nilai } \\
\text { Terendah }\end{array}$ & 52,5 & 57,5 & 60 & 67,5 \\
\hline Rata-rata & 72,30 & 76,54 & 78,85 & 84,81 \\
\hline
\end{tabular}

Kemudian, analisis peningkatan kemampuan pemecahan masalah siswa menggunakan N-Gain pada uji caba I dan II. Hasil perhitungan dari $N$-Gain pada kemampuan pemecahan masalah matematis dapat dilihat pada tabel berikut:

Tabel 12. Rangkuman Hasil N-Gaian Kemampuan Pemecahan Masalah Matematis

\begin{tabular}{cccc}
\hline N-Gain & Interpretasi & $\begin{array}{c}\text { Jumlah } \\
\text { siswa Uji } \\
\text { coba I }\end{array}$ & $\begin{array}{c}\text { Jumlah } \\
\text { siswa Uji } \\
\text { coba II }\end{array}$ \\
\hline $\mathrm{g} \leq 0,3$ & Rendah & 20 & 11 \\
\hline $0,3<\mathrm{g} \leq 0,7$ & Sedang & 5 & 13 \\
\hline $\mathrm{g}>0,7$ & Tinggi & 1 & 2 \\
\hline
\end{tabular}

\section{Peningkatan Kemandirian Belajar Siswa}

Deskripsi peningkatan kemampuan pemecahan masalah menggunakan pengembangan perangkat pemebalajaran berbasis PMR pada uji coba I dan II dapat dilihat pada Tabel 13:

Tabel 13. Rerata Skor uji coba I dan II Kemandirian Belajar Siswa

\begin{tabular}{clcc}
\hline No. & \multicolumn{1}{|c}{ Indikator } & $\begin{array}{c}\text { Rerata } \\
\text { Skor per } \\
\text { Indikator } \\
\text { uji coba I }\end{array}$ & $\begin{array}{c}\text { Rerata Skor } \\
\text { per } \\
\text { Indikator } \\
\text { uji coba II }\end{array}$ \\
\hline 1. & self evaluating & 8,28 & 9,44 \\
\hline 2. & $\begin{array}{l}\text { organizing and } \\
\text { transforming }\end{array}$ & 6,59 & 8,56 \\
\hline 3. & $\begin{array}{l}\text { goal setting and } \\
\text { planning }\end{array}$ & 7,63 & 8,5 \\
\hline 4. & $\begin{array}{l}\text { seeking } \\
\text { information }\end{array}$ & 9,5 & 9,67 \\
\hline 5. & $\begin{array}{l}\text { enviromental } \\
\text { structuring }\end{array}$ & 8,28 & 8,69 \\
\hline 6. & $\begin{array}{l}\text { rehearsing and } \\
\text { memory }\end{array}$ & 7,69 & 8,69 \\
\hline 7. & $\begin{array}{l}\text { seeking per, } \\
\text { teacher, adult } \\
\text { assistance }\end{array}$ & 8,25 & 8,66 \\
\hline 8. & review test/work & 8,56 & 9,06 \\
\hline
\end{tabular}

Untuk melihat kategorisasi kemandirian belajar siswa terdapat pada Tabel 14 
Vol. 13, No.1, Juni 2020

\begin{tabular}{ccccc}
\multicolumn{4}{c}{ Tabel 14. Kategorisasi Kemandirian Belajar Siswa } \\
\hline Skor Siswa & Huruf & Kategori & $\begin{array}{c}\text { Siswa } \\
\text { pada uji } \\
\text { coba I }\end{array}$ & $\begin{array}{c}\text { Siswa } \\
\text { pada uji } \\
\text { coba II }\end{array}$ \\
\hline $76 \%-100 \%$ & A & Baik & 21 & 26 \\
\hline $56 \%-75 \%$ & B & Cukup & 5 & 0 \\
\hline $40 \%-55 \%$ & C & Kurang & 0 & 0 \\
\hline$<40 \%$ & D & $\begin{array}{c}\text { Tidak } \\
\text { baik }\end{array}$ & 0 & 0 \\
\hline
\end{tabular}

Berdasarkan Tabel di atas dapat disimpulkan, bahwa kemandirian belajar siswa setelah menggunakan perangkat pembelajaran berbasis PMR yang dikembangkan meningkat dari Uji coba I ke Uji coba II.

\section{KESIMPULAN}

Berdasrkan hasil analisis dan pembahan dalam penelitian, maka dapat disimpulkan sebagai berikut:

1. Dihasilkan perangkat pembelajaran yang berkualitas yang dikembangkan berdasarkan pendekatan matematika realistik. Perangkat pembelajaran tersebut memenuhi kriteai valid, praktis dan efektif.

2. Peningkatan kemampuan pemecahan masalah matematis siswa menggunakan perangkat pembelajaran berbasis pendekatan matematika realistik pada materi bangun datar segiempat adalah $30 \%$, pada posttest uji coba I ketuntasan klasikal sebesar $62 \%$ dan uji coba II $92 \%$.

3. Peningkatan kemandirian belajar siswa menggunakan perangkat pembelajaran berbasis pendekatan matematika realistik pada materi bangun datar segiempat adalah rata-rata pencapaian kemandirian belajar siswa pada uji coba I sebesar 64,78 dengan kategori rendah dan meningkat menjadi 71,25 pada uji coba II dengan kategori tinggi.

\section{UCAPAN TERIMA KASIH}

Pada kesempatan ini penulis mengucapkan terima kasih kepada :

1. Teristimewa kepada kedua orang tua saya Ayahanda Banua Hsb dan Ibunda Nuraini Daulay dan adik-adikku tersayang yang senantiasa memberikan perhatian, kasihsayang, nasihat, motivasi, do'a dan dukungan baik moril maupun materi yang takterhingga.

2. Bapak Prof. Dr. Sahat Saragih, M.Pd sebagai Pembimbing I dan Bapak Drs. Zul Amry, M.Si, Ph.D sebagai Pembimbing II yang telah meluangkan waktu disela-sela kesibukannya untuk memberikan bimbingan, arahan dan saran-saran yang sangat berarti bagi penulisan tesis ini sampai dengan selesai.

3. Bapak Prof. Dr. Edi Syahputra, M.Pd dan Bapak Dr. Mulyono, M.Si selaku ketua dan sekretaris Program Studi Pendidikan Matematika Pascasarjana UNIMED yang memberikan arahan, nasihat dan semangat serta Staf Program Studi Pendidikan Matematika yang telah membantu

penulis khususnya dalam administrasi perkuliahan di Unimed.

4. Direktur, Asisten Direktur I, dan II beserta Staf Program Pascasarjana Universitas Negeri Medan yang telah memberikan bantuan dan kesempatan kepada penulis menyelesaikan tesis ini.

5. Kepala sekolah, Wakil Kepala Sekolah, Kepala kurikulum, Tata Usaha serta guru-guru dan siswa SMPN 5 Padangsidimpuan yang telah memberikan kesempatan kepada penulis untuk melakukan penelitian lapangan.

\section{REFERENSI}

Arikunto, S. 2009. Penelitian Tindakan Kelas. Jakarta : Bumi Aksara

Atun, I. 2006. Pembelajaran Matematika Dengan Strategi Kooperatif Tipe Student Achievment Divisions Untuk Meningkatkan Kemampuan Pemecahan masalah dan Komunikasi Siswa. Tesis tidak diterbitkan. Bandung: Program Pasca Sarjana UPI Bandung.

Dahlan, J. A. 2012. Implementasi Strategi Pembelajaran Konflik Kognitif dalam Upaya Meningkatkan High Order Mathematical Thinking Siswa. Jurnal Pendidikan, Vol. 13 No. 2, 65-76.

Daulay, A. S. 1998. Ilmu Pendidikan. Medan: CV Jabal Rahmat

Ellinawati, S. W. 2010. Pemanfaatan Model Self Regulated Learning Upaya Meningkatkan Kemampuan Belajar Mandiri pada Mata Kuliah Optik. Jurnal Pendidikan Fisika Indonesia. ISSN: 1693-1246. 35-39.

Fahradina. N., Ansari, B I., \& Saiman. 2014. Peningkatan Kemampuan Komunikasi Matematis dan Kemandirian Belajar Siswa SMP dengan Menggunakan Model Investigasi Kelompok. Jurnal Didakti Matematika, Vol. 1, No. 1, 54-64.

Fauzan, A dan Yerizon. 2013. Pengaruh Pendekatan RME dan Kemandirian Belajar Terhadap Kemamampuan Matematis Siswa. Prosiding Semirata FMIPA Universitas Lampung. 7-14.

Fauzi, KMS. A. 2002. Pembelajaran Matematika Realistik Pada Pokok Pembahasan Pembagian di SD. Tesis pada PPS UNESA: Tidak diterbitkan.

Herman. 2012. Pengembangan Perangkat Pembelajaran Model Pengajaran Langsung Untuk Mengajarkan Materi Kesetimbangan Benda Tegar. Jurnal Sains dan Pendidikan Fisika. Vol. 8, No, 1. 1-11.

In'am, A. 2014. The Implementation of the Polya Method in Solving Euclidean Geometry Problems. Internasional Education Studies. Vol. 7, No. 7, 149-158.

Ja'far, M., Sunardi, \& Indah, A. K. 2014. Pengembangan Perangkat Pembelajaran Berbasis Karakter Konsisten dan Teliti Menggunakan Pendekatan Realistic Mathematics Education (RME) pada Bab Kesebangunan dan Kekongruenan Bangun Dtar Kelas IX SMP. Jurnal Edukasi UNEJ. Vol. I, No. 3, 29-35.

Laurens, T., Adolfina, F. B., Rafafy, J. B., \& Leasa, M. 2017. How Does Realistic Mathematics Education 
(RME) Improve Students' Mathematics Cognitive Achievement?. EURASIA Journal of Mathematics, Science and Technology Education, DOI: $10.12973 /$ ejmste/76959. Vol. 14, No. 2, $569-578$.

Mu'tadin, Z. 2002. Kemandirian sebagai Kebutuhan Psikologis Remaja. Internet. http://www.epsikologi.com/remaja.050602.

Mulyono, A. 2003. Pendidikan Bagi Anak Berkesulitan Belajar. Jakarta: Rineka Cipta.

NTCM. 2000. Principles and Standarts for mathematics, Reaston, VA : NTCM.

Pratama, S., Minarni. A., \& Saragih. S. 2017. Development of Learning Devices Based on Realistic Approach Integrated Context Malay Deli Culture To Improve Ability of Understand Mathematical Concepts and Students' SelfRegulated Learning At SMP Negeri 5 Medan. Journal of Mathematics (IOSR-JM), Vol. 13, Issue 6, 18-29.

Riduwan. 2010. Belajar Mudah Penelitian untuk GuruKaryawan dan Peneliti Pemula. Bandung: Alfabeta.

Rohmah, M \& Sutiarso, S. 2017. Analysis Problem Solving in Mathematical Using Theory Newman. EURASIA Journal of Mathematics, Science and Technology Education, Vol. 14, No. 2, 671-681.

Saragih, S., \& Habeahan, W. 2014. The Improving of Probem Solving Ability and Students' Creativity Mathematical by Using Problem Based Learning in SMP Negeri 2 Siantar. Journal of Education and Practice, Vol. 5, No. 35, 123-132.

Saragih, S \& Napitupulu, E. 2015. Developing StudentCentered Learning Model to Improve High Order Mathematical Thinking Ability. Internasional Education Studies. Vol. 8, No. 6, 104-112.

Surya, E., \& Rahayu, R. 2017. Peningkatan Kemampuan Komunikasi dan Pemecahan Masalah Matematis Siswa SMP AR-Rahman Percut Melalui Pembelajaran Kooperatif Tipe STAD. Jurnal Pendidikan Matematika PARADIKMA, Vol.7, No.1, 24-34.

Szetela, W. \& Nicol, W. (1982). Evaluating Problem Solving in Mathematics. New York: Cambridge University Press.

Tahar, Irzan dan Enceng. 2006. Hubungan Kemandirian Belajar dan Hasil Belajar pada Pendidikan Jarak Jauh. Jurnal Pendidikan Terbuka dan Jarak Jauh, Vol. 7, No. 2, 91-101.

Thiagarajan, S. Semmel, D.S \& Semmel, M.I. 1974. Instructional Development for Training Teachers of Exceptional Children: A sourcebook. Indiana: Indiana University.

Zakaria, E \& Muzakkir, S. 2017. The Effect of Realistic Mathematics Education Approach on Students' Achievement And Attitudes Towards Mathematics. Journal Mathematics Education Trends and Research, Vol. 2017, No.1, 32-40.

Zimmerman, B. J. 2008. Investigating Self-Regulation and Motivation: Historical Background, Methological Developments and Future
Prospects. America: American Educational Research Journal Math, Vol. 45, No.1, 166-183.

Zulkardi \& Ilma. 2010. Pengembangan Blog Support untuk Membantu Siswa dan Guru Matematika Indonesia Belajar Pendidikan Matematika Realistik Indonesia (PMRI). Jurnal Inovosi Perekayasa Pendidikan (JIPP). Vol 2, Issue 1, 1-24. 